Article

\title{
Professionals Made in Germany: Employing a Turkish Migration Background in High-Status Positions
}

\author{
Ali Konyali * and Maurice Crul \\ Department of Public Administration and Sociology, Erasmus University, 3000 DR Rotterdam, The Netherlands; E-Mails: \\ konyali@fsw.eur.nl (A.K.), crul@fsw.eur.nl (M.C.) \\ * Corresponding author
}

Submitted: 27 September 2016 | Accepted: 12 January 2017 | Published: 28 March 2017

\begin{abstract}
This article emphasises the experiences of the prospective elite among the second generation in Germany by analysing empirical data collected through in-depth interviews across three occupational fields (law, education and corporate business). In spite of their disadvantaged background, some children of lower educated migrant parents from Turkey managed to occupy prestigious leadership positions. Many use their ethnic capital in creative and strategic ways to seek opportunities and obtain access to leading positions. They are now embracing new professional roles and have moved into new social circles due to their steep upward mobility. However, they still have to contend with the fact that their individual mobility stands in contrast to the low-status of the group to which they belong.
\end{abstract}

\section{Keywords}

ethnic capital; occupational achievement; professional identity; second generation; social disadvantage; social mobility

\section{Issue}

This article is part of the issue "International Migration and Ethnic Integration", edited by Yaojun Li (University of Manchester, UK) and Anthony Heath (University of Oxford, UK).

(C) 2017 by the authors; licensee Cogitatio (Lisbon, Portugal). This article is licensed under a Creative Commons Attribution 4.0 International License (CC BY).

\section{Introduction}

Even though the Turkish presence has been part of everyday life in Germany's metropolitan areas for many decades, there is still a continuous public demand for their integration based on assumed cultural differences. Against the background of a negative discursive context and in spite of their disadvantageous Turkish migration background ${ }^{1}$ (Crul, Schneider, \& Lelie, 2012; Heath, Rothon, \& Kilpi, 2008), some children of migrants from Turkey have made considerable achievements in Western European labour markets. Whereas extensive research focuses on the recurrent 'failed integration' thesis, professionally successful descendants have received less attention. However, the so-called second generation is entering 'the mainstream' as defined by Alba and Nee
(2009). Climbing toward leading positions, they are embracing new roles and enter new social environments due to their steep upward mobility (Crul \& Schneider, 2010, p. 1253).

Those very successful individuals are of course still socalled exceptions to the rule since their individual mobility stands in stark contrast to the overall group disadvantage of people whose background originates from Turkish migration into Germany. Therefore, this article aims to examine to what extent this contrast is mirrored in their self-conception; we want to examine the choices and reflections around making use of one's ethnic background as part of one's professional capital. The underlying assumption is that on the one hand, these professionals want to be evaluated only according to their merit. On the other hand, their professional selves are closely inter-

\footnotetext{
${ }^{1}$ The term 'Turkish migration background' should not be understood as an imposed homogenization of this group. It is used as a conceptual simplification identifying Turkey as the parental country of origin.
} 
twined with their social selves, and the way others see them. This often results in situations that require them to reassert their professional legitimacy because they do not want to be pigeonholed within an ethnic niche or as 'the Turkish colleague'.

We will study this complicated process for the prospective elite among the second generation in Germany in three different occupational fields (law, education and corporate business). The two research questions of the article are: 1 ) What does it mean to acquire a highstatus professional position in Germany by employing the fact that one belongs to a low-status group? and 2) How does this differ across occupational fields? Thereby, this article will provide an understanding of the patterns which emerge when individuals from a disadvantaged background attain privileged positions by examining the relationship between motivation, recognition and selfperception regarding their career. The data was collected through in-depth interviews with professionals who have lower educated migrant parents. In the following section, we will theorize the consequences of the exceptionally steep individual social mobility and its relationship with social status and group belonging. At the same time, we will discuss to what extent ethnic background resources can be instrumental for one's professional capital. This theoretical framework forms the basis for analysing the professionals' self-conceptions. In the conclusion, we will recapitulate the findings but also debate their implications for the theoretical debate on this issue.

\section{Theoretical Framework}

\subsection{Ethnicity and Low-Status Group Belonging}

Ethnicity is a concept that distinguishes groups of people from each other, whereas the significance and implications of ethnic identities varies across space and time. Social contexts shape ethnic groups as much as these groups shape them. Human interaction, assignment and assertion construct ethnic identities. They are not fixed and static but changeable, contingent, and diverse (Cornell \& Hartmann, 2007). Barth (1969) defines ethnic groups as self-perpetuating, culture-bearing units that are distinguishable from others (p. 296). Thereby, ethnic identity becomes an imperative characteristic which defines peoples' identities and their societal positions ( $p$. 304). Barth's definition emphasises the importance of circumstances by considering the persistent organizational relevance of ethnic identities, even if actual cultural differences might decrease over time (p. 318). This is in line with Brubaker's (2004) definition of ethnicity as a perspective on the world. Challenging the 'groupist' tone in most theorizations on ethnicity, he propagates a focus on processes that are triggered by the 'ethnic lens'. Our conception of ethnicity in this article will follow Brubaker's emphasis on process in relation to social mobility.

According to various studies, descendants of lowskilled migrant parents from Turkey can be seen as the most disadvantaged group when it comes to the educational achievement of children of migrants in Germany (cf. Crul, 2015; Schnell, 2014). Therefore, the German case provides a good illustration of how, for pupils from a migrant background, any disadvantages that may be caused by their parents' migration are combined with those which arise from social class affiliation. The first critical turning point having an effect on children's future in Germany is the transfer from primary school to one of the three levels of secondary education. Ample evidence shows that this decision does not solely depend on individual performance, but also on teachers' recommendations, parents' level of commitment and local education policy. Studies demonstrate that the proportion of Hauptschule recommendations for migrant children is disproportionately higher (Kristen, 2002).

Children of migrants from Turkey tend to have higher ambitions than their peers which seem to be stimulated by the desire to be socially mobile (Salikutluk, 2016; Schneider, Crul, \& Van Praag 2014). This desire is also reflected by their parents' aspirations concerning their children's educational goals (Relikowski, Yilmaz, \& Blossfeld, 2012). Notwithstanding, only a very small minority of this group attends a Gymnasium (high school) and has thereby the opportunity to receive access to higher education (Crul, Schnell, Herzog-Punzenberger, Wilmes, Slootman, \& Aparicio Gómez, 2012).

The effect of a potential disadvantage for children of migrants from Turkey is also visible in terms of there being a longer transition phase from leaving school to entering the labour market, while they also receive lower returns from education concerning occupational attainment (Kalter \& Granato, 2007). For several reasons, there are a number of sectors of the labour market which contain very few people with a background of Turkish migration in Germany (Sürig \& Wilmes, 2015, pp. 82-86). Only a minority of this group enters highly skilled positions in the labour market. Thus, in spite of the fact that considerable intergenerational progress has been observed, this generation still experiences disadvantages in terms of employment and income (Kalter \& Granato, 2007; Worbs, 2003). These overall findings make individuals who have experienced steep upward mobility an exception to the rule.

Institutional arrangements in Germany tend to favour social reproduction which endangers the social mobility of members of the second generation (Worbs, 2003). Even when controlling for formal educational qualifications, descendants of migrants from Turkey remain disadvantaged, which can be attributed to specific labour market discrimination (cf. Seibert \& Solga, 2005; also see Waldring, Crul, \& Ghorashi, 2015, for a study on the Netherlands). However, there might be other potential causes of the specific 'Turkish' disadvantage within Germany. First, descendants of migrants from Turkey lack resources, such as instrumental parental support, to a greater degree than other groups. In addition, the ethnic composition of their friendship networks 
and the fact that they commonly lack language proficiency only further weakens their position (Kalter, 2006). Second-generation Turkish men, in particular, experience higher unemployment, lower re-employment, and higher income-mobility risks at the beginning of their careers due to a lack of country-specific resources which tends to compound their initial disadvantage (Hartmann, 2016b).

The persistence of inequalities is a phenomenon that is not independent of contextual circumstances. Viewing ethnicity as irrelevant because of a statistical insignificance would ignore "the potential causality between ethnicity and social class" (Van de Werfhorst \& Van Tubergen, 2007, p. 434). In our qualitative study, we selected professional success as the dependent variable. As it was indicated above, the institutional arrangements in Germany make individual success dependent upon the availability of family resources and personal circumstances (Hartmann, 2016a; Kalter, 2006). This is what makes our respondents a very select group with exceptional occupational achievements in spite of the double disadvantage of coming from a lower class social origin and having a low-status ethnic background (cf. Crul, Keskiner, \& Lelie, 2017). That is to say, one could justifiably claim that professionally successful descendants of migrants from Turkey, almost by default, can be expected to come from families that were very supportive of their children's education (Crul, Schnell, et al., 2012; Schnell, 2014).

In order to overcome barriers towards attaining skilled positions, highly skilled members of the second generation in Germany have to overcome disadvantages associated with their status as being from a minority throughout their career trajectories (Schittenhelm, 2011). Achieving exceptional success with a devalued social identity might leave individuals with an "inordinate ambivalence and affective dissonance" (Fordham \& Ogbu, 1986, p. 951) and what Ellis Cose (1993) called the "permanent vulnerability of one's status" (p. 41). In spite of professional success, individuals could still be perceived as belonging to the inferior societal out-group. However, paradoxically for the upwardly mobile, ethnicity can also act as a useful social resource in specific professional contexts. For those that have to deal with a restricted career entry, social and cultural capital coming from their Turkish background and Turkish language skills can become relevant as part of their compensatory strategies (Schittenhelm, 2011, p. 115).

\subsection{Ethnicity and Steep Upward Mobility}

In order to comprehend the professional success stories of descendants of migrants from Turkey in Germany, it is necessary to take into account the relativity of structural inequalities for individual cases. This is illustrated by the exceptionality of our respondents and their success, which came about against all odds. But how can this success be explained?

In a previous publication, we described the so-called multiplier effect. We concluded that successful children of immigrants have to make more effort by being more active in using opportunities and loopholes in the system to be as successful as their peers of native descent (Crul, Schneider, et al., 2017). The multiplier effect describes how with each consecutive step in their career they accumulate new cultural and social capital which opens up possibilities to take the next step on the ladder, thereby multiplying their chances of success. This helps them to move up and away from less successful co-ethnics. Although descendants of Turkish immigrants have to overcome their double disadvantage (of ethnic and social origin), their background can also act as a resource which some have used to advance their careers. The reflexivity about their upwardly mobile social identity is an important cornerstone of the multiplier effect. Their starting position within a lower class and background as being a descendant of migrants motivates them and helps them to succeed, although they are aware that they continue to be seen as a representative of a disadvantaged group.

The juxtaposition of ethnic belonging and individual labour market activities is documented in the discussion about migrant entrepreneurship (see Volery, 2007). This type of research, traditionally, has given a lot of importance to ethnic and group-specific resources, arguing that specific cultural properties can enable labour market success (cf. Bonacich, 1973). Recently, there has been increased attention towards highly skilled migrants, often referred to as expats. The emphasis in these studies often lies on temporary skilled migration, knowledge transfer, spatial mobility and networking issues (see e.g. Ackers, 2005; Castles, 2002; Khoo, McDonald, Voigt-Graf, \& Hugo, 2007), as well as transnational ties and the way in which they negotiate multiple identities in the context of well-connected global cities (Favell, 2008). However, in contrast to migrant entrepreneurs and highly skilled migrants, second-generation professionals were either born or raised in the country of their parents' destination. The subjective experiences as belonging to a 'lowstatus' minority group (rather, being perceived as such) are likely to be more influential in shaping their ideas and their narratives about professionalism.

Individuals with an unfortunate social position have to adapt in order to navigate structural constraints (Merton, 1968). Exceptional cases of upward mobility contrast with the image of an unequal and underprivileged socio-economic situation of the migrant majority. Whereas social boundaries are (re-)created through everyday interactions (Elias \& Scotson, 1965), Bourdieu argues that agents embody a deep understanding of appropriate behaviour and act within the structural limits of a field. Individual success depends on the convertibility of the different forms of capital an agent possesses (Bourdieu \& Wacquant, 1992). In other words, ethnicity can be a social boundary that impedes social mobility as well as a social resource that individuals can mobilize in the context of upward mobility processes (Pott, 2001). Through the ethnic lens, in reference to Brubaker, the upwardly mobile professionals might be seen as 'Turkish' but they 
do not fit the stereotype of being poorly educated and doing low-level jobs.

The steep social mobility of the exceptional group we have studied in this article has led to its members being able to occupy professional positions in large (international) firms and organisations. Freidson (1999) views professionalism as specialized work that requires abstract, theoretical knowledge, which "cannot be performed mechanically because...the worker must exercise considerable discretion to adapt his knowledge and skill to each circumstance in order to work successfully" (p. 119). Schinkel and Noordegraaf (2011) additionally view professionalism as a form of symbolic capital. Accordingly, its substance is constantly at stake in powerdriven internal and external contexts. People adjust to their new roles by trying out 'provisional selves' as possible professional identities, while individual and situational factors shape the repertory of possibilities (Ibarra, 1999). One could argue that professionalism necessitates the minimization of individual differences, but this does not mean that it is blind to individual differences. Especially in international companies, being able to deal with people from different nationalities is considered an important professional skill. Pécoud (2002) identifies the emergence of an economic dimension of multiculturalism, which views ethnic pluralism positively, as long as it contributes to the national economy.

The perception of ethnic difference is likely to be different across professional contexts, whereas it determines especially how 'newcomers' such as individuals with a disadvantageous, lower-status background perceive themselves as professionals. Accordingly, in the business sector, visible differences can be promoted as competitive assets. This can lead to achievement narratives of professionals who display their success as individuals who managed to turn their initial group disadvantage into an individual advantage (Konyali, 2014). Coming from a lower-class background and being of immigrant descent can also be a resource in the education and legal sectors because it can be employed in order to establish ties with a specific clientele (Rezai, 2017; Waldring, 2017).

Occupational fields offer distinct opportunity structures in terms of the employment of individual background resources (Crul, Schneider, et al., 2017). The fact that even the highly internationalized corporate business sector is not completely open to 'newcomers' is illustrated by various studies that provide further evidence to the existence of a so-called 'glass ceiling'. The education sector with its emphasis on meritocracy and emancipation is principally against making differentiations based on class and ethnicity, although it is undeniable that there is a middle-class bias among the professionals working in the field. The legal sector with its intrinsic emphasis on equality by law for all social and ethnic groups is at the same time a highly elitist profession, making it necessary for individuals to adapt to the dominant means of behaviour while conducting busi- ness. Thus, there are also different dynamics to be observed across sectors with either an emphasis on, for instance, differentiation (business) or equality (education), which can affect the role played by background characteristics.

\section{Method}

\subsection{Data Collection}

The data consists of interviews conducted within three occupational fields (see Table 1, for an overview of the sample). We have selected individuals working in a professional job who work in mid-level or higher managerial positions. Apart from very few exceptions, most respondents possessed a higher education diploma. As was noted in the theoretical framework, these criteria make them a very select group of respondents. Since we deliberately selected individuals from lower educated families, most of the respondent's parents had not been educated beyond primary school level. This meant that our respondents have usually shown a steep upward mobility. Moreover, individuals were only selected if they had been born in Europe or if they had been raised there and their parents had been born in Turkey. Data was collected through qualitative in-depth interviews in the German metropolitan area of Frankfurt am Main. The final selection of respondents in the business sector included professionals with organizational, managerial or employee responsibilities within a company, as well as professionals occupying a specialist or expert position. In the legal sector, we included lawyers who worked as associates or partners in corporate law firms, lawyers who worked independently or for smaller law firms. Finally, the respondents in the education field were drawn from various professional positions with educational responsibilities, including teaching, training as well as managerial positions.

\subsection{Data Analysis}

The semi-standardized interviews collected information about their educational and professional pathways. In addition, respondents could raise their own issues. The anonymity of all respondents was guaranteed beforehand and the authors changed the names displayed in this article. For the analysis, we made use of the qualitative data analysis software Atlas.ti. The software enabled us to identify dominant themes based on the initial coding of the material. Subsequently, the analysis clarified how the themes related to one another (cf. Bryman, 2015). Two contrasting themes emerged: the first being the importance the respondents attach to ethnic background resources in the respective professional contexts. This was mainly observable by examining the role of their Turkish migration background at work (cf. Section 4.1). The second theme was the importance others attach to this background which was analysed through their reflec- 
Table 1. Overview of sample.

\begin{tabular}{|c|c|c|}
\hline & Year and country of birth & Gender and Position \\
\hline \multirow{7}{*}{ 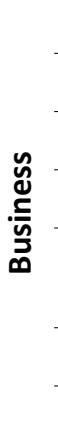 } & 1975 (Germany) & Male, Regional Head of Finance in a professional service company \\
\hline & 1976 (Germany) & Male, CEO in banking \\
\hline & 1971 (Germany) & Female, Senior specialist in banking \\
\hline & 1968 (Germany) & Male, Senior specialist in a professional service company \\
\hline & $\begin{array}{l}1976 \text { (Turkey); came to Germany before } \\
\text { she went to primary school }\end{array}$ & Female, Head of Customer Service in banking \\
\hline & 1974 (Germany) & Male, Independent HR Consultant \\
\hline & 1968 (Germany) & Male, Partner in a professional service company \\
\hline \multirow{7}{*}{$\begin{array}{l}\frac{0}{0} \\
\frac{0}{0} \\
\frac{0}{0} \\
\frac{0}{0}\end{array}$} & 1977 (Germany) & Male, Head of Public Relations of an educational association \\
\hline & $\begin{array}{l}1967 \text { (Turkey); came to Germany before } \\
\text { she went to primary school }\end{array}$ & $\begin{array}{l}\text { Female, Head of training for secondary school teachers at the } \\
\text { teachers' academy of the federal state }\end{array}$ \\
\hline & $\begin{array}{l}1970 \text { (Turkey); in Germany since the age } \\
\text { of seven }\end{array}$ & $\begin{array}{l}\text { Female, Secondary school teacher/appointed to the delegation } \\
\text { office in the Regional Ministry of Education }\end{array}$ \\
\hline & 1974 (Turkey); in Germany since the age of two & Female, Legal trainer at key qualifications office of university \\
\hline & 1982 (Germany) & Male, Chair of local educational umbrella association \\
\hline & 1982 (Germany) & Female, Project manager of a youth organization \\
\hline & $\begin{array}{l}1965 \text { (Turkey); in Germany since the age } \\
\text { of twelve }\end{array}$ & Female, School psychologist \\
\hline \multirow{8}{*}{$\underset{\text { J }}{3}$} & 1978 (Germany) & Female, Independent lawyer \\
\hline & $\begin{array}{l}1972 \text { (Turkey); came to Frankfurt before } \\
\text { he went to primary school. }\end{array}$ & Male, Partner in a corporate law firm \\
\hline & 1979 (Germany) & Male, Associate in a corporate law firm \\
\hline & 1972 (Germany) & Male, Independent lawyer, sharing offices in a small law firm \\
\hline & 1981 (Germany) & Female, Associate in a corporate law firm \\
\hline & 1979 (Germany) & Male, Lawyer in a corporate law firm \\
\hline & 1971 (Germany) & Male, Independent lawyer/owner of a small law firm \\
\hline & 1962 (Germany) & Female, Independent lawyer in a small law firm \\
\hline
\end{tabular}

tions on crucial interactions with significant others such as clients or colleagues (cf. Section 4.2).

\section{Analysis}

\subsection{Professionals Who Meet the Demands}

Without exception, the interviewed respondents were aware of their disadvantaged starting position resulting from their belonging to a low-status group. Retrospectively, many managed to turn this disadvantage into their advantage by adapting themselves to the professional context in question. Their ability to convert their ethnic capital into a valuable professional resource is a key aspect of their upward mobility (cf. Bourdieu \& Wacquant, 1992; Pott, 2001). This happens in different ways across the occupational fields. One way to do so is to carve out a niche by catering to a specific clientele or taking over responsibilities that relate to Turkey.

The business professionals operate in a predominantly internationalized corporate setting. Making use of background resources to build a professional profile was an important part of their narratives. In the following quote, a respondent working in the banking sector explains how he lobbied his own company to focus more on Turkish-speaking clients. Partly by making use of his 'ethnic capital' and corresponding vision of expansion, he was able to climb the ladder in his company:

"It was my initiative. Before I ended up at this position, I was already quite successful within this company by focusing on the Turkish community.... I told the management that I have a concept in mind.... They found it very interesting. Because, I think when you are try- 
ing to work with Turkish people, it is important to be able to conduct that work in their mother tongue in order to show them that you share common values. That makes working with them much easier. Because it is like that, I mean in the end people want to understand and they want to be understood. This is not different in the financial sector. I have told them this very well. I have said that this is why I am so successful here and that we can spread this around the country by multiplying this concept. Eventually, they agreed and a project team was built." (Male, CEO in banking)

In other cases, the use of ethnic resources was only important in a transitional period of careers. Nevertheless, the need to employ one's background of Turkish migration for a competitive advantage was often present. In general, business professionals assumed that having migrant parents equipped them with skills that helped them succeed in a professional context:

"I think that my migration background has given me a lot of things. I mean it provided me with certain soft skills that enabled me to work towards this position. That for sure. However, nobody said, "he is a Turk and that is why we will promote him'. Not at all." (Male, Regional Head of Finance)

The use of background resources seems to work slightly differently for professionals within the education sector. Many professionals we interviewed were intrinsically motivated, having idealistic reasons for working in the field. Most of them linked it to their own background and the felt need to make a difference. Their motivation to provide education is often linked to working for a clientele with a similar background to themselves. A belief in the necessity for change and their capability to contribute to this change drives them, no matter how small the subsequent changes might still be. These ideas also shape their career plans:

"But when I applied, it seemed important to me that this post will be filled with someone who has an immigrant background and not necessarily that they take me, so it should be someone who is well qualified for this place and, uh, that was what was important to me. I just told myself that it would be a pity if I do not apply and no one else with a migration background applies." (Female, Secondary school teacher/appointed to the delegation office in the regional Ministry of Education)

The ability to recognize themselves as necessary newcomers in this field actually helped some of them to advance in their careers and to acquire their current position. But entering positions that were usually not occupied by persons with a migration background, they also have to cope with being the exception to the rule:
"I find that just I am somehow already quite exotic in my area, in my professional field. And unfortunately, some colleagues who worked here for some time already, are not used to that. So, they look at you and test you. It is not a normality, to say the least." (Female, Head of training for secondary school teachers at the teachers' academy of the federal state)

In the field of law, we interviewed both independent and corporate lawyers. Whereas independent lawyers usually have individual clients, corporate lawyers often advise national and international companies. Similar to the respondents in the corporate business sector, many of the lawyers seized the opportunity to specifically take over responsibilities relating to the upcoming market in Turkey and Turkish-German business clients in Germany. These efforts included building active networks in the field. This is illustrated by the fact that next to being a member of the regular German Bar Association, most lawyers we interviewed were also a member of the German-Turkish lawyers' association. In particular, independent lawyers talked about how this gives them an inherent advantage when compared to other independent lawyers without a migration background:

"Unfortunately, I have to say that I see colleagues who have severe difficulties. Because I can offer a range of services that others cannot. I mean especially German colleagues who have language deficiencies. I have to say that my potential clientele is larger, I get more mandates, and I have more possibilities. For instance, being able to do something like a German-Turkish law firm, that makes a difference." (Female, Independent lawyer)

Similarly, corporate lawyers have been able to move their career forward by actively forging ahead with the 'Turkish' agenda and more, in general, the international agenda of their company:

"I think I made myself quite well known in the last three to four years. I am considered as one of the leading consultants overlooking Turkish transactions, both in Turkey and here in Germany. So, the work I am now performing has a quite strong connection to Turkey. Right now I am managing an acquisition in Turkey. But not only there, also in India, I am responsible as an international advisor." (Male, Partner in a corporate law firm)

Thereby they profit from the perception of others who think that they can bridge cultural barriers as trustworthy and competent professionals. Particularly for those in larger corporate firms, climbing the ladder is a crucial part of their identity as a professional, earning them respect in the company but it is also manifested in their self-perception. 
The examples in this section show that 'professional selves' are not only highly affected by disadvantageous structural contexts that operate throughout their upwardly mobile career trajectory, but also by their individual background resources (cf. Ibarra, 1999). It provides them with an additional repertory for establishing themselves in a high-status position. The next section will show how our respondents cope with instances that remind them of the ambiguity that is involved when individuals experience a steep upward social mobility with the help of a background that is usually associated with lowstatus positions. This 'double-edged sword' is illustrated by situations and encounters that remind them of their disadvantageous background.

\subsection{Better Than 'Others' but Still Inferior?}

As we have argued in the theoretical framework of this article, having a Turkish background in Germany, means that one is considered as belonging to a low-status group with an inferior position in society (cf. Worbs, 2003). Most of our respondents already belong to a select group of individuals who have survived the stratified German school system that does not frequently provide the children of migrants from Turkey even the chance to reach higher education. However, as has been illustrated, the fact that there is a large population with a Turkish migration background in Germany and the intertwined business relations between Germany and Turkey can enable individuals to employ their background to their advantage. The tension caused by the usefulness of ethnic resources on the one hand, and the potential threat it poses to the equal treatment of individuals on the other, is present in our respondents' reflections. It is striking that the three different professional contexts we researched each offer different coping mechanisms to refute questions regarding their professionalism.

Respondents in the business sector stated that the stigma of being of Turkish descent was a motivating factor to 'do better', whereas they also encountered instances which challenged their professionalism by problematizing their ethnic background:

"There were again and again cases of clients as well as colleagues where I would say that we were not a good match. This could have happened everywhere of course, but there were comments where I thought, 'did he now really mean to confront me with this? Was this really the person he does not like, or the Turk?'” (Male, Senior specialist in a professional service company)

Coping with the fact that they belong to a low-status group plays a continuous role in their professional selfconception. They do not want to victimize themselves, which is why they hesitate to label potentially discriminatory encounters as such. However, they also do not want to deny the relevance of their ethnic and social background. The following quote shows that this asks for a constant alertness and continuous effort to be accepted as a professional in the company:

"I think that as a Turk in a German company, you have to make sure that you do not attract too much attention....Therefore, I think it is important that you are a little more eager to succeed. One at least always thinks about having to be better than the others are. There is some truth to that." (Male, Partner in a professional service company)

Their motivation to be successful, at least partly, also seems to have its origin in their lower-class background as respondents always refer to the hard manual labour their parents conducted; a clear motivating memory to do better. They tend to display a strong individual achievement narrative in which they present their story as one of a constant search for opportunities against the background of a huge group disadvantage (also see Konyali, 2014). Although this entrepreneurial mindset does not protect them from discriminatory encounters per se, it provides them with a work ethic that is in line with the dominant self-made paradigm in the field.

The education sector is organized very differently. Professionals in this sector were either motivated to educate students, conduct research or move into administrative positions. They can have a sizable impact on the development of the field as well as on the planning of the educational system.

On the one hand, respondents argued that their ethnic and social background should be secondary in their professional context. On the other hand, they were aware of their exceptional position as someone with a Turkish background and they acknowledged that they are filling an important gap:

\begin{abstract}
"What I am happy about is that children see, 'oh as a Turk you can also reach certain positions'. For instance, here we do not have a single Turkish school principal. In the neighbouring city, we had one....She told me that children would go to her office to see if she can really speak Turkish. They tested her. And then they were happy, saying 'I also want to become the head of the school'." (Female, School psychologist)
\end{abstract}

Most of all, they tried to avoid being cornered as a 'special expert' on migrant children only. There is a very explicit desire for acceptance as a professional:

"Well, this certainly changed in comparison to the founding years of this association. For example, we organized a contest and then many parents of German children were also there of course-they were saying 'you have many Turks in your association, we did not expect this!' - so they could not derive from the professionalism involved that many people with a migration background were part of the organization." (Male, Head of Public Relations of an educational association) 
It seems that, in the field of education, those individuals who wish to initiate change within the educational system want to downplay the perception that they work on something meant to exclusively benefit children with a migration background. The educational professionals are very aware of the dangers of being put in the 'ethnic niche', which could damage their image of being professional and competent.

Working in the field of law entails again other interactions with clients and superiors and other criteria for acceptance and professionalism. Lawyers are able to solve problems or represent interests but, above all, they are responsible for the compliance with rules by individuals, groups or institutions in all domains of society. In order to become a practicing lawyer, all respondents needed to follow a thoroughly institutionalized educational pathway, including completing undergraduate and graduate degrees, examinations and licensing procedures. Simply put, they had to be willing to commit several years to studying law in order to become a professional. This institutional set up can also become a legitimizing mechanism when their professionalism is contested:

"Having a foreign sounding name means that one has to prove oneself again and again. This started with my job interview here at this company. I was told the following: 'please tell us something about yourself, so that I can hear if your German is really as good as you claim in your application'....There were of course others present during the job interview, and I said: 'I hope your colleague sitting next to you is an expert in employment law in order to enlighten you about the consequences of such a question'." (Female, Associate in a corporate law firm)

Consequently, there is also an observable difference among lawyers who work in corporate firms and those who are independent or work in smaller firms. Whereas the former group were motivated by their own success and individual motives, the latter often have the added ambition to provide help. However, what they have in common is their ambition to succeed in making a better living than their parents within a very prestigious professional position.

In general, we have shown that elements of individuals' ethnic background can help them move upwards in the labour market. This is not to say that they do not complicate their experiences on the 'way up' at the same time. Even individuals who are professionally successful cannot avoid the experience of discrimination and of being 'othered'. However, it seems that they are better equipped to reflect on their situation and thereby come up with coping mechanisms that help them avoid a further self-victimization (cf. Slootman, 2014).

\section{Conclusion}

In the German public discourse being 'Turkish', is a category that usually leads to the marginalization of indi- viduals as being lower educated, doing lower level jobs and potentially forming a so-called Parallelgesellschaft. These generalizations are an almost daily experience for people of Turkish descent in Germany. This is not to victimize the respondents we discussed in this paper, but it is important to understand how their success was accomplished and seen by others with that societal perspective in mind. It truly happened 'against all odds', as they were not supposed to 'make it'. Their own background, being of lower educated parents from Turkey is constantly reflected in their success stories. They have all attained leading professional positions although there are important differences across occupational fields as these each offer distinct opportunity structures within the given context.

The experience in the three occupational fields is different, which has an observable effect on the respondents' claim of professionalism. To begin with, in spite of many recent developments towards internationalization of education, the nation-state continues to determine the arrangements in the educational sector. In contrast to the business professionals who act within an internationally standardized context where intercultural skills are perceived as a prerequisite, educational professionals face a much more ambiguous process of recognition by their colleagues and supervisors. Individual lawyers, in turn, can employ their migration background more straightforwardly in an entrepreneurial manner. Many have started independent law offices focusing on a clientele of Turkish origin. The corporate lawyers are very similar to the business professionals who work in an increasingly international context, which further legitimizes the position they acquired.

The findings indicate that the value of ethnicity as an individual resource across professional contexts is dependent on the organizational importance that is attached to individual difference. The risk of being pigeonholed by parents and other colleagues in the educational field stands in clear contrast to the way corporate companies perceive 'diversity' amongst their staff as an asset. This is not to say that business professionals are not confronted with instances that question their professionalism, as this is certainly the case. However, for corporate professionals, these confrontations occur more on a personal level, which is easier to cope with for individuals when they look at the issue from a professional point of view. Independent lawyers' claim to professionalism and its contestation is similar to the business professionals and their entrepreneurial attitude, they do however lack the strong organizational backing and subsequent acknowledged professionalism that corporate lawyers enjoy.

With this article, we also demonstrated the nuances of "ethnical capital" and its relation to being a member of a low-status group. The findings of this article point out that employing one's individual background is a 'doubleedged' phenomenon. On the one hand, our respondents clearly benefitted from the employment of their Turkish migration background. On the other hand, they also 
experienced encounters and situations that highlighted the dividing line between themselves and others in spite of their professional success. This underlines the cognitive dimension of ethnicity as "a way of seeing and interpreting the world" (Brubaker, 2004, p. 184). Even if one can see interactions as those displayed in the empirical material as part of the process of 'normalization', one should keep in mind the enduring impact of stigmatization based on being a member of a particular ethnic group, which can have detrimental consequences for individuals who are not in a position to employ ethnic background resources to their advantage.

Being successful in balancing making use of ethnic capital on the one hand and avoiding being stigmatized or pigeonholed on the other hand is an important reflexive quality our respondents needed to develop to be able to position themselves successfully as professionals in their sectors. As such, the often-strategic social identity building efforts and work they needed to undertake provides a further crucial building block to understand how the theoretical concept of the multiplier effect works for this specific group that is successful against all odds (Crul et al., 2017). They often need to carve out alternative routes to leadership positions involving the use of ethnic capital resources. However, they can only do this successfully if they can simultaneously avoid, or actively counter, narratives of stigmatization. The form this takes is different across sectors, but in all cases, it is crucial for the acceptance of their professional identity among colleagues, supervisors and clients.

\section{Acknowledgments}

We would like to thank three anonymous reviewers for helpful comments on an earlier draft of this article. This work was supported by the European Research Council [284223].

\section{Conflict of Interests}

The authors declare no conflict of interests.

\section{References}

Ackers, L. (2005). Moving people and knowledge: scientific mobility in the European Union. International migration, 43(5), 99-131.

Alba, R., \& Nee, V. (2009). Remaking the American mainstream: Assimilation and contemporary immigration. Harvard: Harvard University Press.

Barth, F. (1969). Ethnic groups and boundaries. In W. Sollors (Ed.) (1996), Theories of Ethnicity: a classical reader (pp. 294-324). New York: New York University Press.

Bonacich, E. (1973). A theory of middleman minorities. American Sociological Review, 38(5), 583-594.

Bourdieu, P., \& Wacquant, L. J. (1992). An invitation to reflexive sociology. Chicago: University of Chicago Press.
Brubaker, R. (2004). Ethnicity without groups. Harvard: Harvard University Press.

Bryman, A. (2015). Social research methods. Oxford: Oxford University Press.

Castles, S. (2002). Migration and community formation under conditions of globalization. International migration review, 36(4), 1143-1168.

Cornell, S., \& Hartmann, D. (2007). Ethnicity and race: making identities in a changing World (2nd ed.). London: Pine Forge Press.

Cose, E. (1993). The rage of a privileged class. New York: HarperCollins.

Crul, M. (2015). Is education the pathway to success? A comparison of second generation Turkish professionals in Sweden, France, Germany and the Netherlands. European Journal of Education, 50(3), 325-339.

Crul, M., Keskiner, E., \& Lelie, F. (2017). The upcoming new elite among children of immigrants: a crosscountry and cross-sector comparison. Ethnic and Racial Studies, 40(2), 209-229.

Crul, M., Schneider, J., Keskiner, E., \& Lelie, F. (2017). The multiplier effect: how the accumulation of cultural and social capital explains steep upward social mobility of children of low-educated immigrants. Ethnic and Racial Studies, 40(2), 321-338.

Crul, M., Schnell, P., Herzog-Punzenberger, B., Wilmes, M., Slootman, M., \& Aparicio Gómez, R. (2012). School Careers of Second-Generation Youth in Europe: Which Education Systems Provide the Best Chances for Success? In M. Crul, J. Schneider, \& F. Lelie (Eds.), The European Second Generation Compared: Does the Integration Context Matter? (pp. 101-164). Amsterdam: Amsterdam University Press.

Crul, M., \& Schneider, J. (2010). Comparative integration context theory: participation and belonging in new diverse European cities. Ethnic and Racial Studies, 33(7), 1249-1268.

Crul, M., Schneider, J., \& Lelie, F. (2012). The European second generation compared: does the integration context matter? Amsterdam: Amsterdam University Press.

Elias, N., \& Scotson, J. (1965). The Established and the Outsiders. London: Cass.

Favell, A. (2008). Eurostars and Eurocities: free movement and mobility in an integrating Europe. Oxford: Blackwell.

Fordham, S., \& Ogbu, J. U. (1986). Black students' school success: coping with the "burden of 'acting white'". The Urban Review, 18(3), 176-206.

Freidson, E. (1999). Theory of professionalism: method and substance. International Review of Sociology, 9(1), 117-129.

Hartmann, J. (2016a). Do second-generation Turkish migrants in Germany assimilate into the middle class?. Ethnicities, 16(3), 368-392.

Hartmann, J. (2016b). Assimilation im Lebensverlauf? Die Karrieremobilität von türkischen Männern der zweiten Generation in Deutschland. Zeitschrift für Soziologie, 45(4), 281-297. 
Heath, A. F., C. Rothon, \& Kilpi, E. (2008). The second generation in Western Europe: education, unemployment, and occupational attainment. Annual Review of Sociology, 34, 211-35.

Ibarra, H. (1999). Provisional selves: experimenting with image and identity in professional adaptation. Administrative Science Quarterly, 44(4), 764-791.

Kalter, F., \& Granato, N. (2007). Educational hurdles on the way to structural assimilation in Germany. In A. F. Heath, \& S. Y. Cheung (Eds.), Unequal chances: ethnic minorities in Western labour markets (pp. 271-320). Oxford: Oxford University Press.

Kalter, F. (2006). Auf der Suche nach einer Erklärung für die spezifischen Arbeitsmarktnachteile von Jugendlichen türkischer Herkunft. Zeitschrift für Soziologie, 35(2), 144-160.

Khoo, S. E., McDonald, P., Voigt-Graf, C. \& Hugo, G. (2007). A global labor market: factors motivating the sponsorship and temporary migration of skilled workers to Australia. International Migration Review, 41(2), 480-510.

Konyali, A. (2014). Turning disadvantage into advantage: achievement narratives of descendants of migrants from Turkey in the corporate business sector. New Diversities, 16(1), 107-121.

Kristen, C. (2002). Hauptschule, Realschule oder Gymnasium?. Kölner Zeitschrift für Soziologie und Sozialpsychologie, 54(3), 534-552.

Merton, R. K. (1968). Social theory and social structure. New York: Simon and Schuster.

Pécoud, A. (2002). 'Weltoffenheit schafft Jobs': Turkish entrepreneurship and multiculturalism in Berlin. International Journal of Urban and Regional Research, 26(3), 494-507.

Pott, A. (2001). Ethnicity and social mobility: the case of Turks in Germany. Journal of International Migration and Integration/Revue de l'integration et de la migration internationale, 2(2), 169-186.

Relikowski, I., Yilmaz, E., \& Blossfeld, H. P. (2012). Wie lassen sich die hohen Bildungsaspirationen von Migranten erklären? Eine Mixed-Methods-Studie zur Rolle von strukturellen Aufstiegschancen und individueller. Kölner Zeitschrift für Soziologie und Sozialpsychologie, Sonderheft, 52, 111-136.

Rezai, S. (2017). Self-made lawyers? Pathways of socially mobile descendants of migrants from Turkey in Europe. Ethnic and Racial Studies, 40(2), 230-246.

Salikutluk, Z. (2016). Why Do Immigrant Students Aim
High? Explaining the Aspiration-Achievement Paradox of Immigrants in Germany. European Sociological Review, 32(5), 581-592.

Schinkel, W., \& Noordegraaf, M. (2011). Professionalism as symbolic capital: materials for a Bourdieusian theory of professionalism. Comparative Sociology, 10(1), 67-96.

Schittenhelm, K. (2011). Overcoming barriers. Career trajectories of highly skilled members of the German second generation. In M. Wingens, M. Windzio, H. D. Valk, \& C. Aybek (Eds.), A life-course perspective on migration and integration (pp. 101-119). Dordrecht: Springer Science.

Schneider, J., Crul, M., \& Van Praag, L. (2014). Upward mobility and questions of belonging in migrant families. New Diversities, 16(1), 1-6.

Schnell, P. (2014). Educational Mobility of SecondGeneration Turks. Amsterdam: Amsterdam University Press.

Seibert, H., \& Solga, H. (2005). Gleiche Chancen dank einer abgeschlossenen Ausbildung? Zum Signalwert von Ausbildungsabschlüssen bei ausländischen und deutschen jungen Erwachsenen. Zeitschrift für Soziologie, 34, 364-382.

Slootman, M. (2014). Reinvention of ethnic identification among second generation Moroccan and Turkish Dutch social climbers. New Diversities, 16(1), 57-70.

Sürig, I., \& Wilmes, M. (2015). The integration of the second generation in Germany: results of the TIES survey on the descendants of Turkish and Yugoslavian immigrants. Amsterdam: Amsterdam University Press.

Van de Werfhorst, H. G., \& Van Tubergen, F. (2007). Ethnicity, schooling, and merit in the Netherlands. Ethnicities, 7(3), 416-444.

Volery, T. (2007). Ethnic entrepreneurship: a theoretical framework. In L. P. Dana (Ed.), Handbook of research on ethnic minority entrepreneurship. A co- evolutionary view on resource management (pp. 30-41). Cheltenham; Northampton: Edward Elgar.

Waldring, I. (2017). Practices of change in the education sector: professionals dealing with ethnic school segregation. Ethnic and Racial Studies, 40(2), 247-263.

Waldring, I., Crul, M., \& Ghorashi, H. (2015). Discrimination of second-generation professionals in leadership positions. Social Inclusion, 3(4), 38-49.

Worbs, S. (2003). The second generation in Germany: between school and labor market. International Migration Review, 37(4), 1011-1038.

\section{About the Authors}

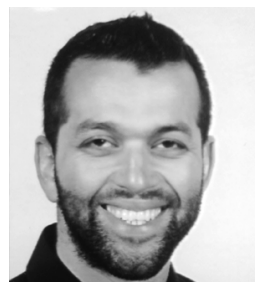

Ali Konyali is a PhD candidate within the framework of the ERC funded ELITES: Pathways to Success project at the Department of Public Administration and Sociology at Erasmus University Rotterdam, The Netherlands. He studied Arts and Culture and European Studies at Maastricht University, The Netherlands, as well as International Migration and Ethnic Relations at Malmö University, Sweden. 


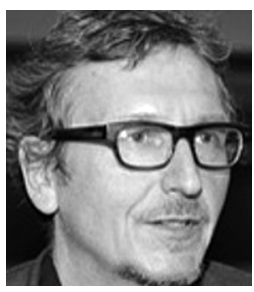

Maurice Crul (PhD) is a Professor at the Free University in Amsterdam and the Erasmus University in Rotterdam. He is co-director of IMISCOE, a network of European research institutes in the fields of migration and diversity. In the last twenty years, he mostly worked on the topic of education and children of immigrants, first within the Dutch context and then in a comparative European and transatlantic context. He is the coordinator of the ELITES: Pathways to Success project. 